\title{
Renal Glomerular Hyperfiltration is Associated with Poor Prognosis in Acute ST-Elevation Myocardial Infarction
}

\section{Renal Glomerüler Hiperfiltrasyon Akut ST-Yükselmeli Miyokard İnfarktüsünde Kötü Prognoz ile Illișkilidir}

\author{
(D) Ahmet Zengin, (D) Mehmet Baran Karataș, (D) Yiğit Çanga, (D) Gündüz Durmuş, (D) Özge Güzelburç, \\ (D) Nizamettin Selçuk Yelgeç, (D) Ayşe Emre
}

İstanbul Dr. Siyami Ersek Thoracic and Cardiovascular Surgery Training and Research Hospital, Clinic of Cardiology, İstanbul, Turkey

\begin{abstract}
Introduction: Glomerular hyperfiltration is related to several clinical conditions, such as prediabetes and prehypertension, and associated with poor prognosis in long-term follow-up. This study aims to elucidate the relationship between glomerular hyperfiltration and short-term prognosis in patients with STsegment elevation myocardial infarction (STEMI) treated by percutaneous coronary intervention (PCI).

Methods: A total of 1,402 patients ( $24 \%$ women, $n=338)$ who had been diagnosed with STEMI and treated by primary PCI were enrolled in the present study. Glomerular hyperfiltration was defined an estimated glomerular filtration rate (GFR) above the $95^{\text {th }}$ percentile based on age- and sex-specific distributions, and a low-filtration rate was defined as an estimated GFR below the $5^{\text {th }}$ percentile. GFR was assessed using the Chronic Kidney Disease Epidemiology Collaboration equation. The major adverse cardiovascular events (MACE) considered in this work included acute stent thrombosis, re-infarction, cardiogenic shock, and cardiac death within 30 days.

Results: MACE was observed in 178 patients (12.6\%). High and low GFRs led to higher risks of developing major cardiovascular events [odds ratio (OR): 1.92, 95\% confidence interval (Cl): 1.19-3.08, $\mathrm{p}<0.01$ and OR: 2.50, 95\% Cl: 1.50-4.17, $\mathrm{p}<0.01$, respectively] compared with normal GFRs. Low ejection fraction, atrial fibrillation, previous coronary artery disease, and low systolic blood pressure were other independent risk factors influencing MACE rates in the multivariable regression models.
\end{abstract}

Conclusion: Glomerular hyperfiltration is independently correlated with short-term MACE rates in patients with acute STEMI treated by primary PCI.

Keywords: Glomerular hyperfiltration, acute myocardial infarction, prognosis

\section{öz}

Amaç: Glomerüler hiperfiltrasyonun pre-diabetes, prehipertansiyon gibi birçok klinik durumla ilişkili olduğu ve uzun dönem takipte daha kötü prognoz ile ilișkili olduğu bilinmektedir. Amacımız perkütan koroner girișimlerle (PKG) tedavi edilen ST-segment yükselmeli miyokard enfarktüslü (STYME) hastalarda glomerüler hiperfiltrasyon ile kısa dönem prognoz arasındaki ilişkiyi aydınlatmaktır.

Yöntemler: STYME tanısı alan ve primer PKG ile tedavi edilen toplam 1.402 hasta (\%24 kadın $n=338$ ) bu çalıșmaya dahil edildi. Glomerüler hiperfiltrasyon, yaşa ve cinsiyete göre dağılımda 95. persentilin üzerindeki değerler olarak tanımlanırken, düşük filtrasyon hızı 5. persentilin altındakiler olarak tanımlandı. Glomerüler filtrasyon oranı Chronic Kidney Disease Epidemiology Collaboration equation formülüne göre hesaplandı. Majör kardiyovasküler olaylar 30 gün içerisindeki akut stent trombozu, re-infarkt, kardiyojenik şok ve kardiyak ölümden oluștu.

Bulgular: Yüz yetmiş sekiz hastada $(\% 12,6)$ majör kardiyovasküler olaylar geliști. Hem düşük hem de yüksek glomerüler filtrasyon oranı, majör kardiyovasküler olay gelişiminde [olasılık oranı (OR): 1,92\%95 güven aralığı (CI): 1,19-3,08, $p<0,01$ ve OR: $2,50 \% 95 \mathrm{Cl}: 1,50-4,17, p<0,01$ sırası ile] normal glomerüler filtrasyon oranı ile karşılaştırıldığında daha yüksek riskliydi. Düşük ejeksiyon fraksiyonu, atriyal fibrilasyon, önceki koroner arter hastalığı ve düşük sistolik kan basıncı multivariate regresyon analizinde kötü prognoz için diğer bağımsız risk faktörleri idi.

Sonuç: Glomerüler hiperfiltrasyonun, primer PKG ile tedavi edilen STYME hastalarında 30 günlük kısa dönemde majör kardiyavasküler olaylar ile bağımsız bir șekilde ilișkili olduğu saptandı.

Anahtar Kelimeler: Glomerüler hiperfiltrasyon, akut miyokard enfarktüsü, prognoz

Cite this article as/Atıf: Zengin A, Karataş MB, Çanga Y, Durmuş G, Güzelburç Ö, Yelgeç NS, Emre A. Renal Glomerular Hyperfiltration is Associated with Poor Prognosis in Acute ST-Elevation Myocardial Infarction. İstanbul Med J 2021; 22(3): 180-5.

(c) Copyright 2021 by the University of Health Sciences Turkey, Istanbul Training and Research Hospital/Istanbul Medical Journal published by Galenos Publishing House 


\section{Introduction}

Chronic kidney disease (CKD) is a health problem of increasing prevalence that affects millions worldwide (1). Besides causing kidney complications, such as end-stage renal disease, and requiring expensive treatments, such as hemodialysis and renal replacement therapy, the disease is a well-known independent risk factor for cardiovascular morbidity and mortality (2). Emerging data indicate that abnormally elevated glomerular filtration rates (GFRs), also called glomerular hyperfiltration, may be a predictor of adverse cardiovascular outcomes (3). Glomerular hyperfiltration is often observed in diabetic patients; however, it is also hypothesized to be related to prehypertension (4), metabolic syndrome, obesity (5), and various renal diseases (6).

Despite the wide availability of potent anti-thrombotic therapies and utility of percutaneous coronary interventions (PCI), acute myocardial infarction (AMI) continues to be a substantial cause of morbidity and mortality. The predictors of short-and long-term outcomes of AMI have been investigated extensively. Vicent et al. (7), for example, demonstrated that older age, female sex, diabetes, multivessel disease, anemia, anterior infarct, prior heart failure, and CKD are related to a higher Killip class and in-hospital mortality in patients with ST-segment elevation myocardial infarction (STEMI) treated by primary PCI (7). A study including 194 acute coronary syndrome patients, $41.2 \%$ of whom had STEMI, indicated that estimated GFR levels below $30 \mathrm{~mL} / \mathrm{min} / 1.73$ $\mathrm{m}^{2}$ could be correlated with unfavorable short- and long-term results (8). However, whether high GFR levels can be used to estimate major adverse cardiovascular outcomes (MACE) in patients with STEMI is unknown.

The characteristics of glomerular hyperfiltration have long been recognized, but its role in cardiovascular diseases has only been recently reported (9). Thus, the present study aims to predict the short-term MACE rates of hyperfiltrators diagnosed with STEMI and treated by primary $\mathrm{PCl}$.

\section{Methods}

\section{Study Population}

Patients diagnosed with STEMI and treated by pPCI between the years 2014 and 2017 were consecutively enrolled in this study. Patients who underwent emergency surgery or had incomplete data were excluded. Patients were classified into the low, normal, or high-filtration groups according to age- and sex-matched GFR levels (Figure 1). Clinical and demographic characteristics and laboratory parameters were obtained from medical records. Short-term MACE rates were the primary outcome, and outcome assessment measures were acquired from hospital records. Informed consent was obtained from all patients, and the study protocol was approved by the İstanbul Dr. Siyami Ersek Thoracic and Cardiovascular Surgery Training and Research Hospital Local Ethics Committee (approval number: 28001928-604.01.01, date: 25.12.2020).

\section{Definitions and Adverse Outcomes}

ST-segment elevation in at least two contiguous leads of $>2 \mathrm{~mm}$ in men and $>1.5 \mathrm{~mm}$ in women accompanied by typical chest pain was defined as STEMI according to the European Society of Cardiology guidelines (10). Stent thrombosis, cardiogenic shock, re-infarction, and cardiac death during index hospitalization and within 30 days were regarded as short-term MACE. Stent thrombosis was defined as definite thrombosis confirmed angiographically within 30 days after first implantation. Cardiogenic shock was defined as persistent hypotension indicated by systolic blood pressure $<90 \mathrm{mmHg}$ or requiring vasopressor support to maintain a level of $>90 \mathrm{mmHg}$ despite adequate filling pressures and evidence of end-organ damage. Acute MI occurring within 28 days after the index event was considered as re-infarction.

GFR levels were estimated via the CKD-EPI equation according to the KDIGO guidelines (11) for white males and females. We referred to previous studies (3) and used the $5^{\text {th }}$ and $95^{\text {th }}$ percentiles as cut-off values produced from age- and sex-specific distributions of eGFR values.

\section{Revascularization Procedure}

All patients underwent invasive evaluation with standard angiographic techniques according to established guidelines. A loading dose of 600 $\mathrm{mg}$ of clopidogrel and $300 \mathrm{mg}$ of acetylsalicylic acid was administered on admission. Then, $100 \mathrm{u} / \mathrm{kg}$ heparin or $1 \mathrm{mg} / \mathrm{kg}$ low-molecular weight heparin were given after the coronary anatomy was identified. The choice of stent type (i.e., bare metal or drug-eluting stents), use of adjunctive therapies (e.g., thrombus aspiration or bailout glycoprotein IIb/IIla receptor antagonist infusion), and adoption of pre/post-dilatation was left to the discretion of the operator. All participants were recommended $75 \mathrm{mg}$ of clopidogrel and acetylsalicylic acid at hospital discharge; other therapies, such as $\beta$ blockers, angiotensin converting enzyme inhibitors, or statins, were also given as necessary unless contraindicated.

\section{Laboratory Parameters and Echocardiography}

Venous blood samples were obtained upon admission to the emergency department before primary $\mathrm{PCl}$. Complete blood counts and biochemical tests were performed using a Beckman Coulter LH 750 and Beckman Coulter LX20, respectively. Serum creatinine levels were measured by the Jaffe method. After primary $\mathrm{PCl}$, all patients underwent two-dimensional and Doppler echocardiographic evaluation to determine their LV ejection fraction; evaluations were conducted by an experienced operator using the Vivid-5 System (General Electric Company, Milwaukee, WI, USA).

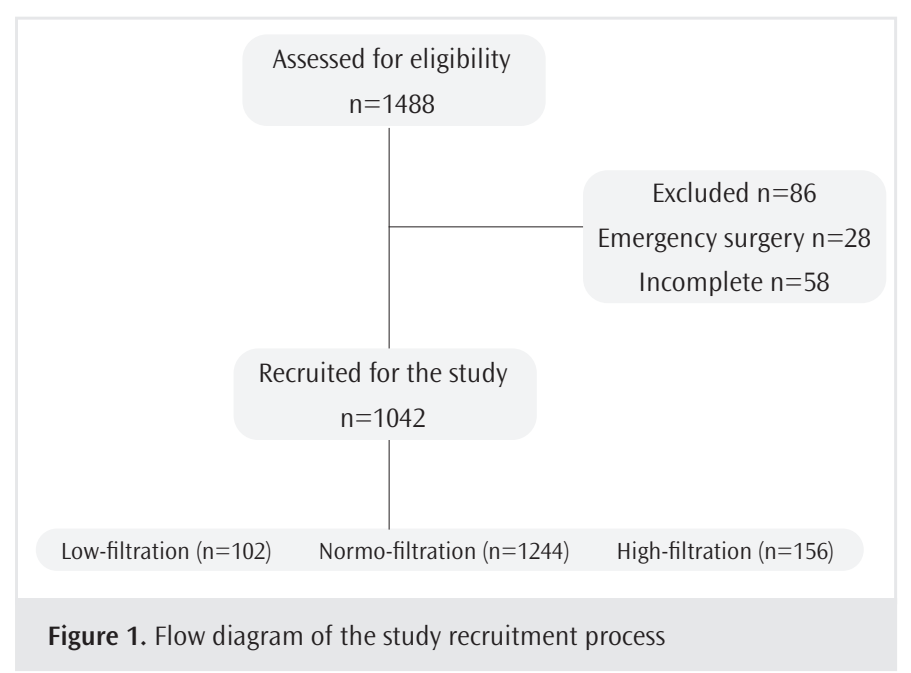




\section{Statistical Analysis}

All data were presented as mean \pm standard deviation for variables with a normal distribution or median (inter-quantile range) for variables with a non-normal distribution. Categorical variables were reported as numbers and percentages. Continuous variables were checked for the normal-distribution assumption by using Kolmogorov-Smirnov statistics. Categorical variables were tested by Pearson's $\chi^{2}$ test and Fisher's exact test. Differences between MACE (+) and MACE (-) patients were evaluated using the Mann-Whitney $U$ test or Student's t-test when appropriate. Univariable and multivariable binary logistic regression analyses were performed to investigate independent correlations with MACE. Variables determined to have $p<0.10$ by univariable regression analysis were included in the multivariable regression analyses. All p-values were two sided, and values of $<0.05$ were considered statistically significant. All statistical studies were conducted using Statistical Package for Social Sciences software (SPSS 22.0 for Windows, SPSS Inc., Chicago, IL, USA).

\section{Results}

A total of 1402 patients [mean age: $57.5 \pm 11.8$ years, $75.8 \%$ male $(n=1064)]$ who had been diagnosed with STEMI were included in this study. The majority of the study population (81.6\%) was included in the normo-filtration group. The frequencies of patients with hyperfiltration and low filtration were $11 \%$ and $7.3 \%$, respectively. The MACEs observed included acute stent thrombosis $(n=40,2.8 \%)$, re-infarction $(n=61$, $4.3 \%)$, cardiogenic shock ( $n=44,3.1 \%)$, and cardiac death $(n=33,2.3 \%)$. Comparisons of the clinical and demographic characteristics of the two groups are depicted in Table 1, 2. The frequencies of smoking, coronary artery disease, atrial fibrillation (AF), and anterior infarct were higher in the MACE $(+)$ group than in the MACE (-) group (p-values of $0.03,<0.01$, $<0.01,0.03$, respectively). Mean LV ejection fraction and systolic blood pressure values were lower in the MACE $(+)$ group than in the MACE (-) group ( $p<0.01$ for both comparisons). The groups were statistically comparable in terms of other parameters.

A comparison of the laboratory parameters of the study groups is provided in Table 3. Compared with those of the MACE (-) group, mean white blood cell, alanine aminotransferase, and aspartate aminotransferase AST levels were higher whereas hemoglobin and lowdensity lipoprotein levels were lower in the MACE (+) group.

We performed univariable and multivariable binary logistic regression analyses for all variables to determine the independent predictors of short-term MACE. During univariable regression analysis, systolic blood pressure, anterior infarct location, LV ejection fraction, heart rate, AF, previous coronary artery disease (CAD), and low and high-filtration rates were found to be correlated with in-hospital and 30-day MACEs. When these parameters were entered into the multivariable regression model, systolic blood pressure (OR: 0.97, 95\% Cl: 0.96-0.98, p<0.01), LV EF (OR: 0.96, 95\% Cl: 0.95-0.97, p<0.01), AF (OR: 2.62, 95\% Cl: 1.21-5.63, $p<0.01$ ), previous CAD (OR: $1.60,95 \% \mathrm{Cl}: 1.07-2.39, \mathrm{p}<0.01)$, low-filtration rate (OR: $2.50,95 \% \mathrm{Cl}: 1.50-4.17, \mathrm{p}<0.01)$, and high-filtration rate (OR: 1.92, 95\% Cl: 1.19-3.08, $\mathrm{p}<0.01)$ were confirmed to be independent predictors of in-hospital MACE. A normal filtration rate was selected as the reference value when low and high-filtration rates were entered into the regression model (Table 4).

We assessed the tolerance and variance inflation factor (VIF) of all parameters included in the regression model to prevent multicollinearity.

Table 1. Demographic properties of the MACE (+) and MACE (-) groups

\begin{tabular}{|c|c|c|c|c|}
\hline Variable & Total $(n=1402)$ & $\operatorname{MACE}(+)(n=178)$ & MACE (-) $(n=1224)$ & p-value \\
\hline Age, years & $57.5 \pm 11.8$ & $58.6 \pm 13.5$ & $57.3 \pm 11.5$ & 0.17 \\
\hline Sex (men), n (\%) & $1064(75 \%)$ & $134(75 \%)$ & 930 (76\%) & 0.83 \\
\hline Diabetes mellitus, n (\%) & $332(23 \%)$ & $52(29 \%)$ & $280(22 \%)$ & 0.06 \\
\hline Hypertension, n (\%) & $624(44 \%)$ & $82(46 \%)$ & $542(44 \%)$ & 0.65 \\
\hline Smoking, n (\%) & $922(66 \%)$ & $130(73 \%)$ & $792(65 \%)$ & 0.03 \\
\hline Hyperlipidemia, n (\%) & $262(18 \%)$ & $28(16 \%)$ & $234(19 \%)$ & 0.27 \\
\hline Family history, n (\%) & $262(19 \%)$ & $32(18 \%)$ & $230(19 \%)$ & 0.79 \\
\hline Previous CAD, n (\%) & $244(17 \%)$ & $48(27 \%)$ & $196(16 \%)$ & $<0.01$ \\
\hline Previous HF, n (\%) & $20(2 \%)$ & $6(3 \%)$ & $14(1 \%)$ & 0.05 \\
\hline Atrial fibrillation, $\mathrm{n}(\%)$ & $38(3 \%)$ & $12(7 \%)$ & $26(2 \%)$ & $<0.01$ \\
\hline
\end{tabular}

Table 2. Clinical characteristics of the MACE (+) and MACE (-) groups

\begin{tabular}{|c|c|c|c|c|}
\hline Variable & Total $(n=1402)$ & $\operatorname{MACE}(+)(n=178)$ & $\operatorname{MACE}(-)(n=1224)$ & p-value \\
\hline Body mass index, $\mathrm{kg} / \mathrm{m}^{2}$ & $23.7 \pm 2.2$ & $23.5 \pm 2.1$ & $23.7 \pm 2.3$ & 0.24 \\
\hline LV ejection fraction, (\%) & $44.3 \pm 10$ & $40 \pm 10.6$ & $45 \pm 9.6$ & $<0.01$ \\
\hline Heart rate, bpm & $80.4 \pm 18.4$ & $82.7 \pm 19.7$ & $80.1 \pm 18$ & 0.08 \\
\hline Systolic blood pressure, $\mathrm{mmHg}$ & $123 \pm 21.9$ & $111 \pm 28.1$ & $124.8 \pm 20.2$ & $<0.01$ \\
\hline Anterior infarct, n (\%) & $606(43.2 \%)$ & $92(51.7 \%)$ & $514(42 \%)$ & 0.03 \\
\hline Multivessel disease & $598(43 \%)$ & $78(44 \%)$ & $520(43 \%)$ & 0.73 \\
\hline
\end{tabular}


All parameters revealed tolerance values $>0.1$ and VIF values $<10$ according to multicollinearity statistics. Thus, no multicollinearity exists between each of the variables in the regression model.

We plotted the relationship between the predicted probability of shortterm MACE and filtration status according to our regression model (Figure 2). The graphic demonstrates that high and low-filtration rates indicate a higher probability of in-hospital MACE compared with normofiltration rates. The mean probabilities of short-term MACE were $31 \%$ in the low-filtration rate group, $18 \%$ in the high-filtration rate group, and $10 \%$ in the normo-filtration rate group.

\section{Discussion}

The major finding of our study is that glomerular hyperfiltration is an independent predictor for short-term MACE in patients with STEMI treated by PCI. We also found an independent association between low GFRs and short-term MACE, as described in previous studies $(7,8)$. To

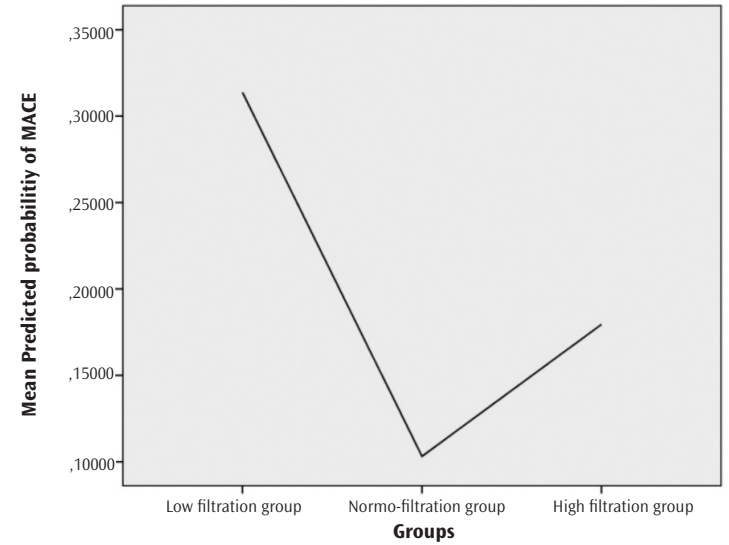

Figure 2. Relationship between predicted probability of MACE and filtration status

MACE: Major adverse cardiovascular events

\begin{tabular}{|c|c|c|c|c|}
\hline Variable & Total $(n=1402)$ & $\operatorname{MACE}(+)(n=178)$ & MACE (-) $(n=1224)$ & $p$-value \\
\hline White blood cell, $10^{3} / \mu \mathrm{Lt}$ & $12.9 \pm 3.8$ & $13.2 \pm 4.7$ & $12.8 \pm 3.7$ & 0.04 \\
\hline Hemoglobin, g/L & $13.8 \pm 1.6$ & $13.5 \pm 1.9$ & $13.9 \pm 1.6$ & 0.04 \\
\hline Platelet, $/ \mathrm{mm}^{3}$ & $245.7 \pm 74$ & $246.1 \pm 91.3$ & $245.6 \pm 71.3$ & 0.93 \\
\hline First troponin, $\mathrm{ng} / \mathrm{mL}$ & $6.4(38.8)$ & $7.2(48.2)$ & $6.3(36.9)$ & 0.89 \\
\hline C-reactive protein, $\mathrm{mg} / \mathrm{L}$ & $3.9(16.8)$ & $12(17.3)$ & $3.4(16.8)$ & 0.18 \\
\hline $\mathrm{HbA} 1 \mathrm{c}, \mathrm{mmol} / \mathrm{L}$ & $6.2 \pm 3.5$ & $6.4 \pm 2.6$ & $6.1 \pm 3.6$ & 0.35 \\
\hline Total cholesterol, mg/dL & $190.5 \pm 45.7$ & $190.6 \pm 50.3$ & $190.5 \pm 45.1$ & 0.98 \\
\hline LDL cholesterol, mg/dL & $119.6 \pm 36.1$ & $114.1 \pm 36.2$ & $120.3 \pm 36$ & 0.03 \\
\hline HDL cholesterol, mg/dL & $37.8 \pm 10.6$ & $37.6 \pm 12.5$ & $37.5 \pm 10.3$ & 0.80 \\
\hline Triglyceride, $\mathrm{mg} / \mathrm{dL}$ & $162.3 \pm 90.5$ & $161.1 \pm 94.9$ & $162.5 \pm 88$ & 0.84 \\
\hline Sodium, $\mathrm{mEq} / \mathrm{L}$ & $137.1 \pm 6.6$ & $137.5 \pm 5.1$ & $137.1 \pm 6.7$ & 0.35 \\
\hline Potassium, $\mathrm{mEq} / \mathrm{L}$ & $4.1 \pm 0.5$ & $4.2 \pm 0.6$ & $4.1 \pm 0.5$ & 0.05 \\
\hline AST, IU/L & $35(72)$ & $76(128)$ & $34(63)$ & 0.03 \\
\hline ALT, IU/L & $31(37)$ & $56(75.5)$ & $29.5(31.7)$ & 0.04 \\
\hline Uric acid, mg/dL & $6.2 \pm 1.6$ & $6.2 \pm 1.8$ & $6.2 \pm 1.6$ & 0.97 \\
\hline Serum glucose, mg/dL & $135.3 \pm 80.6$ & $164 \pm 90.4$ & $131.1 \pm 74.3$ & 0.05 \\
\hline $\mathrm{GFR}, \mathrm{mL} / \mathrm{min} / 1.73 \mathrm{~m}^{2}$ & $92.5 \pm 22.6$ & $87.2 \pm 28.8$ & $93.2 \pm 21.4$ & $<0.01$ \\
\hline Normo-filtration & $1244(81.6 \%)$ & $118(66.3 \%)$ & $1026(83.8 \%)$ & $<0.01$ \\
\hline Hyperfiltration & $156(11 \%)$ & $28(15.7 \%)$ & $128(10 \%)$ & $<0.01$ \\
\hline Low filtration & $102(7.3 \%)$ & $32(18 \%)$ & $70(5.7 \%)$ & $<0.01$ \\
\hline
\end{tabular}

AST: Aspartate aminotransferase, ALT: alanine aminotransferase, GFR: glomerular filtration rate, HDL: high-density lipoprotein, LDL: Iow-density lipoprotein, MACE: major adverse cardiovascular events, HbA1c: hemoglobin A1c

\section{Table 4. Independent predictors of short-term MACE in multivariate regression analysis}

\begin{tabular}{|l|l|l|}
\hline Variable & Adjusted OR (\%95 Cl) & p-value \\
\hline Systolic blood pressure & $0.97(0.96-0.98)$ & $<0.01$ \\
\hline LV ejection fraction & $0.96(0.95-0.98)$ & $<0.01$ \\
\hline Atrial fibrillation & $2.62(1.21-5.63)$ & $<0.01$ \\
\hline Previous CAD & $1.60(1.07-2.39)$ & $<0.01$ \\
\hline Low filtration & $2.50(1.50-4.17)$ & $<0.01$ \\
\hline Hyperfiltration & $1.92(1.19-3.08)$ & $<0.01$ \\
\hline
\end{tabular}

MACE: Major adverse cardiovascular events, CAD: coronary artery disease, OR: odds ratio, Cl: confidence interval, LV: left ventricular, CAD: coronary artery disease 
the best of our knowledge, the present study is the first to demonstrate increased short-term MACE in patients with acute STEMI and glomerular hyperfiltration.

Glomerular hyperfiltration can occur as a physiological consequence of pregnancy or high protein consumption, and it is hypothesized to be the initiating event of GFR decline and progression to end-stage renal disease in many conditions, especially diabetes mellitus (12). Glomerular hyperfiltration could be identified in $70 \%$ and $50 \%$ of type 1 and 2 diabetes mellitus patients, respectively, in the early course of the disease (6). Glomerular hyperfiltration has been also shown to be related to hypertension $(4,13)$ and smoking and obesity $(5,14)$. Interestingly, the condition has been demonstrated to be an independent predictor of all-cause mortality and cardiovascular events in low-risk populations or healthy subjects $(9,15)$. Dupuis et al. (16) concluded that glomerular hyperfiltration is associated with increased cardiovascular events, with a risk profile similar to that of stage 3a CKD, in healthy middle-aged subjects. In addition, subclinical cardiovascular indicators, such as left ventricular hypertrophy, coronary artery calcium score, and carotid artery atherosclerosis, are relatively high in glomerular hyperfiltration (17-19).

The exact mechanism of glomerular hyperfiltration and its relation to cardiovascular events has not been well examined. Increased activity of the RAAS and sympathetic nervous system have been shown to be related to glomerular hyperfiltration due to glomerular hypertension $(20,21)$. Persistent activation of neurohormonal systems and their role in ventricular remodeling and left ventricular functions in the acute phase of MI are well known. This mechanism may help explain why patients with glomerular hyperfiltration are more susceptible to low ejection fraction and cardiogenic shock in the context of STEMI than those without. Increased adrenergic tone has been demonstrated to cause glomerular hyperfiltration by increasing renal plasma flow (22) and is known to be a risk factor for arrhythmic complications and death during the course of AMI (23). On the other hand nitric oxide (NO), a significant vasodilator, has been associated with glomerular hyperfiltration in an experimental model (24). However, while increases in the activity and expression of NO have been observed in the renal microcirculation, only low levels of the substance are detected in the systemic circulation, resulting in endothelial dysfunction. Decreased vasodilatation due to low NO levels in the ischemic myocardium may lead to increases in infarct size and short-term MACE rates. Finally, decreases in the plasma levels of some renally excreted drugs, such as clopidogrel, low-molecular weight heparin, and glycoprotein Ilb/IIla receptor antagonists, may promote the development of acute stent thrombosis or re-infarction.

Mortality and morbidity remain high despite improvements in the treatment of patients with STEMI. A recent meta-analysis showed MACE rates ranging between $4.2 \%$ and $51 \%$ (25). In our study, the MACE rate was $12.6 \%$. Compared with patients with normal filtration rates, patients with glomerular hyperfiltration had a 1.9-fold increased risk while those with low filtration had a 2.5-fold increased risk of developing short-term MACE. These results agree with a previous study that demonstrated a 2.2fold increase in risk for short-term MACE whom eGFR $<60 \mathrm{~mL} / \mathrm{min} / 1.73$ $\mathrm{m}^{2}$ presented with AMI compared with patients had eGFR $>60 \mathrm{~mL} /$ $\min / 1.73 \mathrm{~m}^{2}$ (26). Our data demonstrate that glomerular hyperfiltration is a significant risk factor for adverse events, such as CKD, in patients with STEMI. Specifically, a U-shaped relationship was observed between GFR levels and short-term MACE rates.

A major confounding factor for research on this topic is the vague definition of glomerular hyperfiltration in the literature. Despite growing evidence, no clear cut-off value has yet been identified to quantify glomerular hyperfiltration. While the majority of the available trials tend to use a single threshold value, other works adopt age- and sex-specific thresholds to define glomerular hyperfiltration. Indeed, $30 \%$ of the related studies in the literature report no clear cut-off values (27). Thus, in this work, our definition of glomerular hyperfiltration depended on age- and gender-specific adjusted cut-offs, as proposed by Cachat et al. (27). This approach allowed us to avoid categorizing older patients into the renal insufficiency group inappropriately on account of the remarkable decline in GFR that often accompanies aging. Similarly, younger patients are not misclassified as hyperfiltrators solely on the basis of their GFR. Most of the studies in the literature use estimated GFR values, rather than objective measurements, because of the latter technique is time-consuming and expensive. Overall, our results indicate that glomerular hyperfiltration rates based on estimated ageand gender-specific distributions could predict short-term MACE rates in patients diagnosed with STEMI and treated by primary $\mathrm{PCI}$.

\section{Study Limitations}

Our study includes several limitations. While our findings suggest that glomerular hyperfiltration is independently correlated with short-term MACE in STEMI patients, we could not establish a causal relationship between these parameters. We estimated GFRs using a predefined formula rather than direct measurement. Our data were acquired from a Turkish population and may not be generalizable to other ethnic groups. In addition, we could not assess the protein and salt consumption and muscle mass of the patients, all of which could alter filtration rates. Finally, our study is only a single-center retrospective study.

\section{Conclusion}

Our findings indicate that glomerular hyperfiltration may be a significant predictor of short-term MACE in patients with STEMI treated by primary $\mathrm{PCl}$. Identifying patients with hyperfiltration may be of great value in efforts to manage this patient subgroup. Further studies are needed to confirm our findings.

Ethics Committee Approval: The study protocol was approved by the İstanbul Dr. Siyami Ersek Thoracic and Cardiovascular Surgery Training and Research Hospital Local Ethics Committee (approval number: 28001928-604.01.01, date: 25.12.2020).

Informed Consent: Informed consent was obtained from all patients.

Peer-review: Externally peer-reviewed.

Authorship Contributions: Concept - A.Z., M.B.K.; Design - A.Z., A.E.; Data Collection or Processing - A.Z., Ö.G., N.S.Y.; Analysis or Interpretation - A.Z., M.B.K.; Literature Search - A.Z., Y.Ç., G.D.; Writing - A.Z., Y.Ç., G.D., A.E. 
Conflict of Interest: No conflict of interest was declared by the authors.

Financial Disclosure: The authors declared that this study received no financial support.

\section{References}

1. Bikbov B, Purcell CA, Levey AS, Smith M, Abdoli A, Abebe M, et al. GBD Chronic Kidney Disease Collaboration. Global, regional, and national burden of chronic kidney disease, 1990-2017: a systematic analysis for the Global Burden of Disease Study 2017. Lancet 2020; 395: 709-33.

2. Webster AC, Nagler EV, Morton RL, Masson P. Chronic Kidney Disease. Lancet 2017; 389: 1238-52.

3. Reboldi G, Verdecchia P, Fiorucci G, Beilin LJ, Eguchi K, Imai Y et al. Glomerular hyperfiltration is a predictor of adverse cardiovascular outcomes. Kidney Int 2018; 93: 195-203.

4. Palatini P, Dorigatti F, Saladini F, Benetti E, Mos L, Mazzer A, et al, Factors associated with glomerular hyperfiltration in the early stage of hypertension. Am J Hypertens 2012; 25: 1011-6.

5. Sasson AN, Cherney DZ. Renal hyperfiltration related to diabetes mellitus and obesity in human disease. World J Diabetes 2012; 3: 1-6.

6. Helal I, Fick-Brosnahan GM, Reed-Gitomer B, Schrier RW. Glomerular hyperfiltration: definitions, mechanisms and clinical implications. Nat Rev Nephrol 2012; 8: 293-300

7. Vicent L, Velásquez-Rodríguez J, Valero-Masa MJ, Diez-Delhoyo J, GonzalezSaldivar H, Bruna V, et al. Predictors of high Killip class after ST segment elevation myocardial infarction in the era of primary reperfusion. Int J Cardiol 2017; 248: 46-50

8. Uemara Y, Ishikawa S, Takemato K, Negishi Y, Tanaka A, Takagi K, et al. $\mathrm{N}$-registry investigators. Clinical outcomes after percutaneous coronary intervention in non-dialysis patients with acute coronary syndrome and advanced renal dysfunction. Clin Exp Nephrol 2020; 24: 339-48.

9. Kanbay M, Ertuglu LA, Afsar B, Ozdogan E, Kucuksumer ZS, Ortiz A, et al. Renal hyperfiltration defined by high estimated glomerular filtration rate: A risk factor for cardiovascular disease and mortality. Diabetes Obes Metab 2019; 21: 2368-83.

10. European Society of Cardiology Clinical Practice Guidelines Acute Myocardial Infarction in Patients Presenting with ST Segment Elevation (Management of) Guidelines European Heart Journal 2018; 39: p. 26.

11. National Kidney Foundation KDIGO Clinical Practice Guideline for the Evaluation and Management of CKD. Am J Kidney Dis 2012; 63: p. 7.

12. Palatini P. Glomerular hyperfiltration: a marker of early renal damage in prediabetes and pre-hypertension. Nephrol Dial Transplant 2012; 27: 1708-14.

13. Okada R, Yasuda Y, Tsushita K, Wakai K, Hamajima N, Matsuo S. Glomerular hyperfiltration in prediabetes and prehypertension. Nephrol Dial Transplant 2012; 27: 1821-5.
14. Serpa Neto A, Bianco Rossi FM, Dal Moro Amarante R, Alves Bruti N, Cunha Barbosa Saheb G, Rossi M. Effect of weight loss after Roux-en-Y gastric bypass, on renal function and blood pressure in morbidly obese patients. J Nephrol 2009; 22: 637-46.

15. Park M, Yoon E, Lim YH, Kim H, Choi J, Yoon HJ. Renal hyperfiltration as a novel marker of all-cause mortality. J Am Soc Nephrol 2015; 26: 1426-33.

16. Dupuis ME, Nadeu-Fredette AC, Madore F, Agharazii M, Goupil R. Association of Glomerular Hyperfiltration and Cardiovascular Risk in Middle-Aged Healthy Individuals. JAMA Netw Open 2020; 3: e202377.

17. Choi HM, Hyun YY, Lee KB, Kim H. High estimated glomerular filtration rate is associated with coronary artery calcification in middle-aged Korean men without chronic kidney disease. Nephrol Dial Transplant 2015; 30: 996-1001.

18. Schmieder RE, Messerli FH, Garavaglia G Nunez B. Glomerular hyperfiltration indicates early target organ damage in essential hypertension. JAMA 1990; 264: 2775-80.

19. Ericsen BO, Løchen ML, Arntzen KA, Bertelsen G, Eilertsen BA, Hanno T, et al. Subclinical cardiovascular disease is associated with a high glomerular filtration rate in the nondiabetic general population. Kidney Int 2014; 86 : 146-53.

20. Sochett EB, Cherney DZ, Curtis JR, Dekker MG, Scholey JW, Miller JA. Impact of renin angiotensin system modulation on the hyperfiltration state in type 1 diabetes. J Am Soc Nephrol 2006; 17: 1703-9.

21. Schmieder RE, Veelken R, Schobel H, Dominiak P, Mann JF, Luft FC. Glomerular hyperfiltration during sympathetic nervous system activation in early essential hypertension. J Am Soc Nephrol 1997; 8: 893-900.

22. Tidgren B, Hjemdahl P. Renal responses to mental stress and epinephrine in humans. Am J Physiol 1989; 257: F682-9.

23. Janse MJ, Wit AL. Electrophysiological mechanisms of ventricular arrhythmias resulting from myocardial ischemia and infarction. Physiol Rev 1989; 69: 1049-169.

24. Cherney DZ, Reich HN, Jiang S, Har R, Nasrallah R, Hébert RL, et al. Hyperfiltration and effect of nitric oxide inhibition on renal and endothelia function in humans with uncomplicated type 1 diabetes mellitus. Am J Physiol Regul Integr Comp Physiol 2012; 303: 710-8.

25. Poudel I, Tejpal C, Rashid H, Jahan N. Major Adverse Cardiovascular Events: An Inevitable Outcome of ST-elevation myocardial infarction? A Literature Review. Cureus 2019; 11: e5280.

26. Blasco L, Sanjuan R, Carbonell N, Solís MA, Puchades JH, Torregrosa I, et al. Estimated Glomerular Filtration Rate in Short-Risk Stratification in Acute Myocardial Infarction. Cardiorenal Med 2011; 1: 131-8.

27. Cachat F, Combescure C, Cauderay M, Girardin E, Chehade H. A systematic review of glomerular hyperfiltration assessment and definition in the medical literature. Clin J Am Soc Nephrol 2015; 10: 382-9. 